\title{
Role of Perceived Value and Emotions in the Satisfaction and Future Intentions of Spectators in Sporting Events
}

\author{
Ferran Calabuig-Moreno $^{1}$, Josep Crespo-Hervas ${ }^{1}$, Juan Nunez-Pomar ${ }^{1}$, Irena Valantine ${ }^{2}$, Inga \\ Staskeviciute-Butiene ${ }^{2}$
}

${ }^{1}$ University of Valencia

FCAFE, Gasco Oliag, 3, 46010 Valencia, Spain

E-mail.ferran.calabuig@uv.es, josep.crespo@uv.es, juan.m.nunez@uv.es

${ }^{2}$ Lithuanian Sports University

Sporto str., 6, Kaunas, Lithuania

E-mail.irena.valantine@lsu.lt,inga.staskeviciute@lsu.lt

cross $^{\text {ref }}$ http://dx.doi.org/10.5755/j01.ee.27.2.12288

\begin{abstract}
The quality of service offered by sports entities has become a good predictor of user satisfaction and also future intentions. To know the future intentions of customers of any service is a key objective to develop service improvement and retention strategies. This need has also become apparent to professional sports clubs. In this study, the relationship between perceived quality (tangibles, staff, complementary services and outcome quality), perceived value, emotions, satisfaction and future intentions of spectators are analyzed for a sporting event. Consequently, the main objectives proposed in this study were to test a model of causal relationships whereby the perceived value is a function of perceived quality, satisfaction is a consequence of quality, perceived value and emotions, and future intentions are a function of satisfaction and perceived value, and to know the importance of perceived value in predicting future intentions of the spectator. The research was conducted on a basketball club of the Spanish premier league, where 563 spectators were surveyed with a selfadministered questionnaire. The original scale used for the analysis of perceived quality consisted of 9 items with an alternative seven-point response and was called Eventqual-R, that is the short version of Eventqual which is used in the regular leagues of professional basketball. Results indicate that perceived value is the best predictor of the satisfaction and future intentions of spectators, while quality and emotions have limited relevance as predictors of spectator satisfaction.
\end{abstract}

Keywords: Sport Spectators, Satisfaction, Emotions, Future Intentions, Sporting Events, Sport Management.

\section{Introduction}

The analysis of sporting events is a recurring theme in the research on economics and sports management, either to determine the economic impact on host cities (e.g., Baade \& Matheson, 2004; Auruskeviciene, Pundziene, Skudiene, Gripsrud, Nes \& Olsson, 2010; Balciunas, Jasinskas, \& Koika, 2014), to create predictive models of the team victories or to determine the factors that influence spectator satisfaction or intention to repeat attendance (e.g. Theodorakis \& Alexandris, 2008), among others.

In terms of the latter perspective and understanding sporting events as a service, the relationship established between service quality, satisfaction, perceived value and future intentions is a recurring theme in the service literature in general (Cronin, Brady, \& Hult, 2000) and the sports management literature in particular (Kwon, Trail, \& Anderson, 2005). This interest has shifted to the study of service quality and user satisfaction in sporting events (Bodet \& Bernanche-Assollant, 2011). For sporting events, it is important to emphasize Eventqual scale (Calabuig, Mundina, \& Crespo, 2010b) and the SEQSS scale developed by (Ko, Zhang, Cattani \& Pastore, 2011) and (Clemes, Brush \& Collins, 2011).

This interest is promoted by the positive influence of consumer satisfaction with service, as manifested in medium-term benefits such as speaking well of the company, cross-buying and customer loyalty (Anderson, Fornell, \& Lehmann, 1994). It is known that satisfaction is a key element in the strategies for retention and customer loyalty (Cronin et al., 2000), and this is what makes it attractive to sports managers and sports researchers. At sporting events, it has been found that spectator satisfaction is a significant predictor of future intentions to attend (Cronin et al., 2000; Kim, LaVetter, \& Lee, 2006; Wakefield \& Blodgett, 1996), and satisfaction is a consequence of perceived value (Calabuig et al., 2010b; Cronin et al., 2000) and quality (Calabuig et al., 2010b; Tsuji, Bennett, \& Zhang, 2007).

Consequently, the research problem of this paper is to examine the relationship between perceived quality (tangibles, staff, complementary services and outcome quality) and perceived value, satisfaction, emotions and future intentions of spectators.

Given the above mentioned, the objectives proposed in this study are: a) to test a model of causal relationships whereby the perceived value is a function of perceived quality, satisfaction is a consequence of quality, perceived value and emotions, and future intentions are a function of satisfaction and perceived value, and b) to know the importance of perceived value in predicting future intentions of the spectator. 
Research method: comparative analysis of scientific literature was conducted when developing the theoretical analysis; empirical research was executed conducting a quantitative study; structural equations modeling was performed in the empirical research.

\section{Literature Review and Hypotheses}

Spectator perceived quality and satisfaction. Service quality has been defined as a lasting attitude expressed as the difference between expectations and service outcomes (Parasuraman, Zeithmal, \& Berry, 1988). A drawback to this approach is that expectations are certainly difficult to detect and measure. (Cronin \& Taylor, 1992) also agreed that perceived service quality is the difference between expectations and service outcomes while recognizing that the consumer had already assessed the difference when he/she was asked about the outcomes of the service, and they therefore proposed measuring only perception without considering expectations.

Moreover, satisfaction can be defined as the comparison between expectations and perceptions of service quality on the part of the consumer (Shonk \& Chelladurai, 2008). However, from a more hedonic view, it is also understood as a pleasurable reaction to a good or service in an act of consumption (Oliver, 1997). Satisfaction is more volatile and ephemeral and more easily modified with each act of consumption. However, the perceived quality is considered more stable, enduring, and difficult to change.

In the field of sports events service quality has been studied from two perspectives. On the one hand it has adapted the measurement model of SERVQUAL (Parasuraman et al., 1988) to analyze the perceptions of spectators (e.g. McDonald, Sutton, \& Milne, 1995; Theodorakis, Kambitsis, \& Laios, 2001). On the other hand, they have developed specific measurement scales without regard to SERVQUAL (e.g. Jin, Lee, \& Lee, 2013; Kelly \& Turley, 2001; Ko et al., 2011).

Because of the disparity in the types of sporting events and cultures where this construct has been studied, the structure of the quality of service at sporting events is very diverse. There is no consensus on the measure of quality and all studies suggest that the combination of dimensions is the best option to fit well into the framework of study. In this paper, the quality of service is analyzed in a professional basketball club through the dimensions of Tangibles, Staff, and Complementary Services proposed by (Crespo, Mundina, Calabuig, \& Aranda, 2014) which also applied to basketball events. Furthermore, in recent studies the dimension of outcome quality is being incorporated into the measurement model thanks to the proposal of (Brady \& Cronin, 2001). This dimension assesses aspects such as entertainment, game performance, excitement and drama associated with sporting events (Ko et al., 2011). According to (Crespo et al., 2014), the accessibility dimension has not been taken into account in this study due to the type of the event, as it is a regular sports event and fans are accustomed to arrive at the venue and the seats with ease.

Several studies in the field of sports management found that service quality is a predictor of satisfaction (Alexandris, Zahariadis, Tsorbatzoudis, \& Grouios, 2004;
Lee, Kim, Ko, \& Sagas, 2011; Tsuji et al., 2007). In this regard, (Theodorakis et al., 2001) analyze quality as perceived by basketball spectators and determine that the dimensions that have greater weight in predicting satisfaction are reliability and tangibles. (Kelley \& Turley, 2001) observe that the most important attribute is related to the game experience which is part of the outcome quality. (Perez-Campos \& Alonso, 2013) found that tangibles and staff were strong predictors of the satisfaction of handball spectators. Furthermore, (Greenwell, Fink, \& Pastore, 2002) found that tangibles influenced the satisfaction of ice hockey spectators. Likewise, (Tzetzes, Alexandris, \& Kapsampeli, 2014) have confirmed that access quality, venue quality (related to complementary services) and content quality (related to outcome quality) are predictors of spectator satisfaction in a small-scale sporting event.

Thus, the hypotheses that arise are:

H1a. The spectator's perception of staff quality has a positive and significant relationship with satisfaction.

$\mathrm{H} 1 \mathrm{~b}$. The tangibles quality of the event has a positive and significant relationship with spectators' satisfaction.

H1c. The complementary services quality has a positive and significant relationship with spectators' satisfaction.

H1d. The outcome quality has a positive and significant relationship with satisfaction.

Spectator perceived value, satisfaction and future intentions. (Zeithaml, 1988, p.14) defines perceived value as "the consumer's overall assessment of the utility of a product based on perceptions of what is received and what is given". In this regard, (Chen \& Dubinsky, 2003) indicate that consumer perceived value is the perception of a set of gains from an exchange and the cost incurred to obtain the desired benefits. Researchers found that benefit is considered synonymous with quality, and sacrifice is identified with price. (Dodds, Monroe, \& Grewal, 1991) conceptualized perception as a trade-off between perceived monetary sacrifice, quality and value. In that case value is known as perceived cost value.

There are several works indicating that service quality is an antecedent of perceived value (e.g. Chen \& Dubinsky, 2003). We also found some works where this relationship is maintained at sporting events (Cronin et al., 2000), although research in this area has been very limited. Considering quality as a second order factor, (Clemes et al., 2011) found a direct relationship between service quality and perceived value at sporting events. Similarly, (Calabuig et al., 2015) found that the overall quality is a strong antecedent of spectators' perceived value. In this regard, the hypotheses that arise are:

H2a. The staff quality has a direct and positive relationship with the perceived value.

$\mathrm{H} 2 \mathrm{~b}$. The tangibles quality has a direct and positive relationship on the perceived value.

$\mathrm{H} 2 \mathrm{c}$. The complementary services quality has a direct and positive relationship with the perceived value.

$\mathrm{H} 2 \mathrm{~d}$. The outcome quality has a direct and positive relationship with value.

Moreover, many studies consider that satisfaction is a consequence of perceived value (Yang \& Peterson, 2004; Sanchez \& Iniesta, 2006), as is evident from the literature in which this relationship is described (Cronin et al., 2000; 
Gallarza \& Gil, 2006). In terms of sporting events, (Calabuig et al., 2010a; Cronin et al., 2000, and Hightower, Brady \& Baker, 2002) suggest that perceived value is a strong predictor of spectator satisfaction. So, the proposed hypothesis is:

H3a. The spectator perceived value has a positive and direct effect on satisfaction.

(Bagozzi, Gopinath, \& Nyer, 1999) indicate that emotions are responses to assessments or evaluations that one makes about something important that is happening to you or you are experiencing and, they also note the importance of emotions in the assessments made by consumers of products and services.

Moreover, (Kleinginna \& Kleinginna, 1981) define emotion as a complex set of interactions between subjective and objective factors influenced by neural and hormonal systems which can generate: a) affective experiences, such as feelings of pleasure or arousal b) cognitive processes, such as perception and evaluation, c) activation of physiological adjustments, and d) behavior that is usually, but not always, expressive and leads to a goal and is adaptive.

In the field of sports management, there are very few studies addressing the study of emotions as predictors of satisfaction or as influential factors in the behavior of users.

In the context of sports management, (Sumino \& Harada, 2004) find that emotion is a predictor of the intention to attend sports facilities in the future. In fitness centres, (Silla, Calabuig, \& Ano, 2014) also have found that comfort emotion is an antecedent of costumer satisfaction. Furthermore, (Biscaia, Correia, Rosado, Marocco, \& Ross, 2012) found that joy predicted the future intentions and satisfaction of soccer spectators. From another point of view, (Calabuig, Prado-Gasco, Crespo, Nunez, \& Ano, 2015) analyze whether emotions exert a moderating effect on the quality-value-satisfaction-future intentions chain of sporting events spectator. They found that emotions only moderate the effect of service quality on perceived value for both arousal and pleasure conditions. This result suggests that emotions exert direct relations rather than moderating relations.

$\mathrm{H} 3 \mathrm{~b}$. The emotion of pleasure has a direct and positive relationship with spectator satisfaction.

$\mathrm{H} 3 \mathrm{c}$. The arousal emotion has a direct and positive relationship with satisfaction.

Perceived value is a measure of overall consumer perception of the usefulness of a service and is based on perceptions of what is received product and what is given (Zeithaml, 1988). Several studies suggest that perceived value is one of the most important determinants of the intention to repurchase (Lewis \& Soureli, 2006; McDougall \& Levesque, 2000). Some studies on sports management have also confirmed this relationship (e.g., Calabuig, Nunez, Prado, \& Ano, 2014). Moreover, in the specific context of sporting events, the works of (Byon, Zhang, \& Baker, 2013, and Clemes et al., 2011) confirm this relationship in professional sport spectatorship. It also has been found (Calabuig et al., 2015) that perceived value predicts future intentions in a sample of basketball spectators and the same results were found by (Jin et al., 2013) in a World athletics championship. Thus, the hypothesis that arises is:
H4a. There is a direct and positive relationship between spectator perceived value and future intentions.

Regarding the relationship of satisfaction with loyalty, (Chang, Wnag, \& Yanga, 2009) state that satisfaction directly affects customer loyalty, which includes dimensions such as the intention to repurchase, word of mouth and tolerance to price increases (Anderson et al., 1994; Fornell et al., 1996; Zeithmal, 1988). In the marketing literature, the positive influence of satisfaction on intention is recognized by many publications (Cronin \& Taylor, 1992; Wangenheim \& Bayon, 2007; Banyte, Tarute, \& Taujanskyte, 2014), and some of them specifically focus on the field of sports events (Clemes et al., 2011; Cronin et al., 2000; Kim et al, 2006; Kuenzel \& Yassim, 2007; Lee \& Kang, 2015; Theodorakis, Alexandris, Tsigilis, \& Karvounis, 2013; Trail, Anderson, \& Fink, 2005; Wakefield \& Blodgett, 1996). Therefore, the hypothesis to be tested is:

$\mathrm{H} 4 \mathrm{~b}$. There is a direct and positive relationship between spectator satisfaction and future intentions.

Figure 1 summarizes the model of causal relationships and the hypotheses proposed above. As Observed in the Figure 1, the items (observable variables) that make up each factor (unobservable inputs) to facilitate interpretation and display the model relations are obviated.

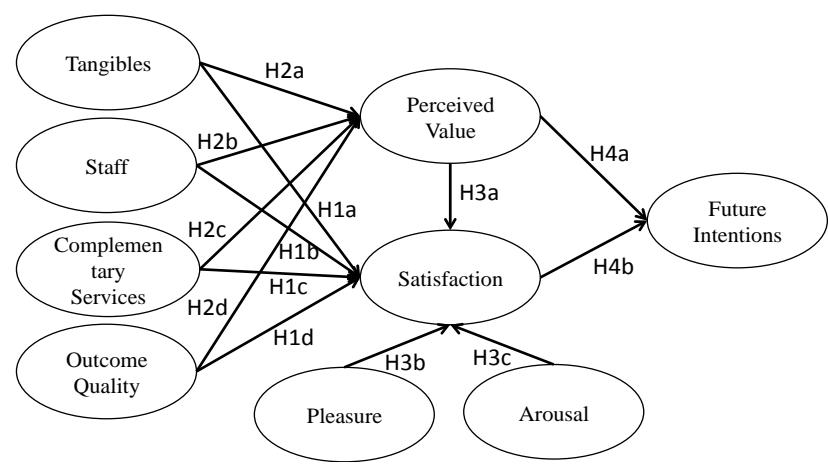

Figure 1. Theoretical model and hypothesis

\section{Methods}

Sample. The research was conducted on a basketball club of the Spanish premier league, where 563 spectators were surveyed with a self-administered questionnaire. The sample comprised $69 \%$ men and $31 \%$ women with a mean age of 36,81 years $( \pm 12,35) ; 49,2 \%$ of respondents were 36 years old or older, and $36 \%$ were between the ages of 24 and $35,14,8 \%$ were between 18 and 23 years old; $17,3 \%$ had primary education, $37,6 \%$ had secondary education, and $45,1 \%$ had college degrees.

Instruments. The original scale used for the analysis of perceived quality consisted of 9 items with an alternative seven-point response ranging from strongly disagree (1) to strongly agree (7) and was taken from (Crespo et al., 2013). This scale, called Eventqual-R, is the short version of Eventqual developed by (Calabuig, Mundina, \& Crespo, $2010 \mathrm{~b}$ ), which is used in the regular leagues of professional basketball. The three resulting quality dimensions are staff, tangibles and complementary services. The dimension of outcome quality (5 items) suggested by (Brady \& Cronin, 2001) was added to this scale. The emotions were assessed through the pleasure dimension (4 items), and arousal (3 items) that were taken from (Russell, 1980). For overall 
Ferran Calabuig-Moreno, Josep Crespo-Hervas, Juan Nunez-Pomar, Irena Valantine, Inga Staskeviciute-Butiene. Role of...

satisfaction, the scale from (Hightower et al., 2002), consisting of 5 items with an alternative seven-point Likertscale response was administered in the study. The perceived value was measured through the 4-item (Hightower et al., 2002) scale (7-point alternative responses). Future intentions were evaluated through 3 items on the Zeithmal et al., (1996) scale with alternative responses of 7 points.

Data analysis. Statistical analysis of data was performed using the SPSS 20 and EQS 6,2 statistics package. First, we proceeded to calculate the descriptive statistics for each item, and then we proceeded to evaluate the reliability and validity of the scale. Finally, a confirmatory factor analysis and structural equation modeling with EQS software were carried out.

\section{Results}

In this section, we will first examine the reliability and validity of the measurement scales used in the research, and subsequently, causal relationships will be discussed in the proposed model.

\section{Validity and reliability of the instruments}

Reliability of instruments: Analysis of the scales used to measure the constructs of the model is divided into two sections; the first one is individual reliability, which subsequently analyzes joint analysis, thus proving the validity and reliability of a concept. For reliability analysis, the following will be used: a) the Cronbach's alpha coefficient as recommended by (Nunnally \& Bernstein, 1994), b) composite reliability coefficient for each of the dimensions, and c) the average variance extracted.

All Cronbach's alpha values were higher than .7. Thus, confirmatory factor analysis (CFA) was applied for further examination. All coefficients higher than .7 exhibited the minimum recommended value of composite reliability (Bagozzi \& Yi, 1988). Table 1 summarizes these results. The average variance extracted (AVE) (Fornell \& Larcker, 1981) reflects the total amount of variance indicators collected by the latent construct. The higher values of AVE are the most representative indicators of the latent variable that loaded, and it is recommended that these values be higher than .50 (Hair, Black, Babin, Anderson, \& Tatham, 2006).

Table 1

Reliability coefficients of the measurement instruments

\begin{tabular}{|l|c|c|c|c|}
\hline \multicolumn{1}{|c|}{ Scale } & $\begin{array}{c}\text { Number of } \\
\text { items }\end{array}$ & $\begin{array}{c}\text { Cronbach's } \\
\text { Alpha }\end{array}$ & CR & AVE \\
\hline Tangibles & 3 & .93 & .93 & .82 \\
Personnel & 3 & .87 & .88 & .70 \\
Complementary & 3 & .87 & .88 & .70 \\
Services & & .83 & .83 & .50 \\
Outcome Quality & 5 & .92 & .92 & .74 \\
Pleasure & 4 & .86 & .86 & .67 \\
Arousal & 3 & .93 & .93 & .72 \\
Satisfaction & 5 & .89 & .89 & .68 \\
Perceived value & 4 & .87 & .88 & .71 \\
Future Intentions & 3 & & & \\
\hline
\end{tabular}

Table 1 indicates how all the constructs will exceed this cut-off, confirming the reliability of the instruments.

Validity of the instruments. This study has analyzed the validity of the scales through convergent validity and discriminant validity. Convergent validity can be checked by analyzing the correlations between the different dimensions that comprise the construct on which you are working (Gomez \& Palaci, 2003). As a construct is analyzed, the dimensions that define it must be correlated with each other significantly.

Thus, the standardized loading weights demonstrated to be significant in their respective dimensions ( $p<.05 ; t>5$ ), and similarly, the correlations between pairs of constructs were also significant. Therefore, we can confirm their convergent validity (Anderson \& Gerbing, 1988).

Discriminant validity was then checked. For this, the correlations between factors were analyzed (Table 2). Correlations between pairs of factors were extracted. All of them were under the square root of AVE for each construct (Fornell \& Larcker, 1981). Moreover, the correlations between pairs of constructs were not excessively high $(<$ .85 ), ensuring the existence of discriminant validity (Kline, 2005).

Table 2

Pearson's correlations among measurement instruments

\begin{tabular}{|c|c|c|c|c|c|c|c|c|c|c|c|}
\hline Dimensions & Mean & SD & 1 & 2 & 3 & 4 & 5 & 6 & 7 & 8 & 9 \\
\hline 1. Tangibles & 4.82 & 1.17 & .903 & & & & & & & & \\
\hline 2. Staff & 5.38 & 1.03 & $.573^{* *}$ & .838 & & & & & & & \\
\hline 3. Complementary services & 4.70 & 1.30 & $.470^{* *}$ & $.495^{* *}$ & .837 & & & & & & \\
\hline 4. Outcome quality & 5.10 & 0.72 & $.282^{* *}$ & $.231^{* *}$ & $.126^{* *}$ & .710 & & & & & \\
\hline 5. Satisfaction & 5.46 & 1.07 & $.542^{* *}$ & $.360^{* *}$ & $.381^{* *}$ & $.405^{* *}$ & .846 & & & & \\
\hline 6. Perceived value & 5.22 & 1.09 & $.635^{* *}$ & $.418^{* *}$ & $.328^{* *}$ & $.410^{* *}$ & $.573^{* *}$ & .822 & & & \\
\hline 7. Future Intentions & 6.25 & 0.88 & $.355^{* *}$ & $.329^{* *}$ & $.200^{* *}$ & $.392^{* *}$ & $.499^{* *}$ & $.491^{* *}$ & .845 & & \\
\hline 8. Pleasure & 3.85 & 0.98 & $.128^{* *}$ & $.115^{* *}$ & $.117^{* *}$ & $.393^{* *}$ & $.375^{* *}$ & $.251^{* *}$ & $.158^{* *}$ & .862 & \\
\hline 9. Arousal & 3.63 & 0.92 & $.204^{* *}$ & $.133^{* *}$ & $.112^{* *}$ & $.361^{* *}$ & $.295^{* *}$ & $.224^{* *}$ & $.182^{* *}$ & $.436^{* *}$ & .820 \\
\hline
\end{tabular}

**. Correlation is significant at the .05 level.

Square root of AVE in bold

Setting the confirmatory factor model. SEM was used to confirm the factor structure of the re-specified perceived quality scale which is composed of 4 dimensions and 14 indicators.

Several fit indices were the basis for assessing the model, including the normed fit index (NFI: Joreskog \&
Sorbom, 1986), incremental fit index (IFI: Bollen, 1989), and comparative fit index (CFI: Bentler, 1990). Other indices are also included such as the chi-square and root mean square error of approximation (RMSEA), which are appropriate for testing the model (Hu \& Bentler, 1999). 
For the indices of NFI, IFI, and CFI, values higher than .90 suggest reasonable fit (Bentler \& Bonett, 1980), and for RMSEA, values lower than .08 indicate reasonable fit (Browne \& Cudeck, 1993).

The results indicate an adequate fit $(\chi 2: 187.76, d f 71, p$ $<.001$; CFI 0.98, NFI: 0.96, IFI: 0.98; RMSEA: 0.046; CI: 0.035-0.056).

Analysis of causal relationships

After checking the reliability and validity of the scales used, we proceed to the analysis of the causal relations model (Kaplan, 2000). The software EQS 6.2 (Bentler, 1995) was used for that purpose. First, indicators to adjust the proposed model were shown, and then the causal relationships were analyzed. In Table 2 , we can find a summary of the results obtained from modeling.

Setting the structural model. The estimation process model was created using maximum likelihood with robust correction Satorra-Bentler (Bentler, 1995). Because the statistical chi-square $(\chi 2)$ is very susceptible to large sample sizes, other indicators were examined, such as the ratio chisquare and degrees of freedom, less than 5 values being acceptable (Byrne, 1989; Carmines \& McIver, 1981). The structural model indicated good indexes of goodness of fit (S-B $\chi 2: 1128.76$, df 475, $p<.001 ;$ S-B $\chi 2 / d f: 2.38$; NFI 0.90, CFI: 0.94, IFI 0.94, RMSEA: 0.053 (IC 0.049 to 0.057)).

Analysis of structural relationships. Regarding the causal relationships of the model (see Table 3 and Figure 2), Hypothesis 1 tested the relationship with quality satisfaction. It was found that the dimensions of tangibles $(\mathrm{H} 1 \mathrm{a}: \beta=.16$; $p<.05)$, complementary services $(\mathrm{H} 1 \mathrm{c}: \beta=.27 ; p<.05)$ and, outcome quality (H1d: $\beta=.15 ; p<.05)$ had a significant and positive effect on satisfaction; however staff (H1b) had no significant effect on spectators' satisfaction.

Table 3

\section{Structural relations, standardized loading and hypothesis testing}

\begin{tabular}{|c|c|c|c|}
\hline Hypothesis & Structural relation & (B) & Test \\
\hline H1a & Tangibles -> Satisfaction & $.16^{*}$ & Supported \\
\hline $\mathrm{H} 1 \mathrm{~b}$ & Staff -> Satisfaction & -.13 & Not supp \\
\hline $\mathrm{H} 1 \mathrm{c}$ & $\begin{array}{l}\text { Complementary services -> } \\
\text { Satisfaction }\end{array}$ & $.27 *$ & Supported \\
\hline H1d & Outcome quality -> satisfaction & $.15^{*}$ & Supported \\
\hline $\mathrm{H} 2 \mathrm{a}$ & Tangibles -> Perceived value & $.53^{*}$ & Supported \\
\hline $\mathrm{H} 2 \mathrm{~b}$ & Staff -> Perceived value & .04 & Not supp \\
\hline $\mathrm{H} 2 \mathrm{c}$ & $\begin{array}{l}\text { Complementary services -> } \\
\text { Perceived value }\end{array}$ & .01 & Not supp \\
\hline $\mathrm{H} 2 \mathrm{~d}$ & $\begin{array}{l}\text { Outcome quality -> Perceived } \\
\text { value }\end{array}$ & $.36^{*}$ & Supported \\
\hline $\mathrm{H} 3 \mathrm{a}$ & Perceived value $->$ Satisfaction & $.37 *$ & Supported \\
\hline $\mathrm{H} 3 \mathrm{~b}$ & Pleasure -> satisfaction & $.20 *$ & Supported \\
\hline $\mathrm{H} 3 \mathrm{c}$ & Arousal -> satisfaction & .06 & Not supp \\
\hline $\mathrm{H} 4 \mathrm{a}$ & $\begin{array}{l}\text { Perceived value -> Future } \\
\text { intentions }\end{array}$ & $.41^{*}$ & Supported \\
\hline $\mathrm{H} 4 \mathrm{~b}$ & Satisfaction -> Future Intentions & $.24 *$ & Supported \\
\hline
\end{tabular}

* Relation is significant at the .05 level

Hypothesis 2 was partially confirmed. There is a direct and positive influence of tangibles dimension $(\mathrm{H} 2 \mathrm{a}: \beta=.53$; $p<.05)$ and outcome quality dimension (H2d: $\beta=.36 ; p<$ $.05)$ on perceived value. However, staff (H2b) and complementary services (H2c) show no significant relationship with perceived value.

The third hypothesis was confirmed partially, i.e. the perceived value $(\mathrm{H} 3 \mathrm{a}: \beta=.37 ; p<.05)$ and pleasure emotion
(H3b: $\beta=.20 ; p<.05$ ) had a positive and significant effect on satisfaction, but arousal emotion was not significant on satisfaction $(\mathrm{H} 3 \mathrm{c})$.

Finally, the 4th hypothesis analyzes the relationship between perceived value and satisfaction on future intentions of spectators. In this regard, the strong effect of the perceived value on future intentions of the spectators is noteworthy (H4a: $\beta=.41, p<.05$ ). Similarly, this has resulted in the expected theoretical relationship between satisfaction and intention $(\mathrm{H} 4 \mathrm{~b}: \beta=.24 ; \mathrm{p}<.05)$ as noted in the literature (Baker \& Crompton, 2000; Oliver et al., 1997), although in this case it is less apparent.

It can be observed in Figure 2 that the stated relations explain a moderately high percentage of the variance of the dependent variables, in this case satisfaction $\left(R^{2}=\underline{0.49}\right)$, the perceived value $\left(\mathrm{R}^{2}=\underline{0.58}\right)$ and future intentions $\left(\mathrm{R}^{2}=\right.$ $\underline{0.35})$.

\section{Discussion and Conclusions}

Regarding the first objective, the results indicate that good indicators of adjustment and reliability and the validity of the measures support the proposed structural model empirically. Regarding quality, spectators perceive four dimensions. These are staff, tangibles, complementary services and outcome. This study has ruled the dimension of accessibility following the suggestion of (Crespo et al., 2013). Accessibility is one dimension that is often present at sporting events (Calabuig et al., 2010b; Clemes et al., 2011; Kelley \& Turley, 2001; Theodorakis \& Alexandris, 2008), but in this case (i.e. regular event), it may indicate that for those events at which spectators are connoisseurs of service, it is not important, or at least, it is not attributable to the quality of the organization of the event, which is one possible explanation. However, further inquiry is necessary to understand why accessibility seems to be irrelevant for spectators of regular events.

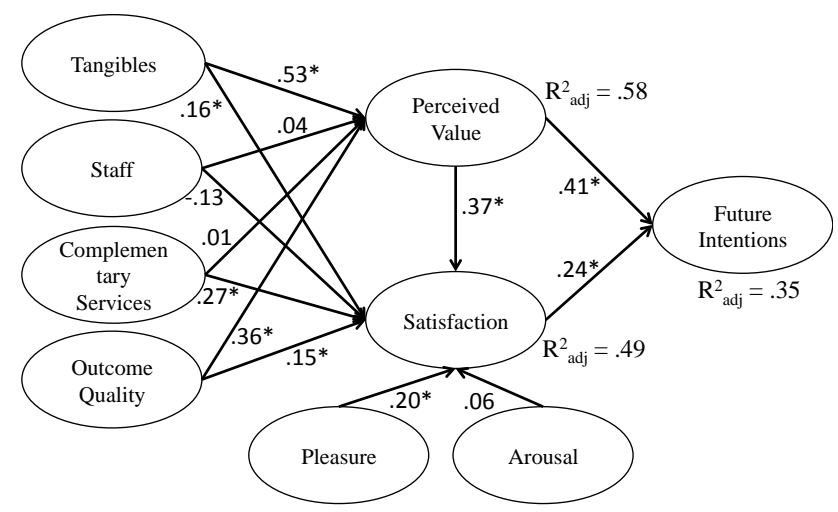

Figure 2. Structural relationships estimated model

* Relation is significant at level .05

It is noteworthy how quality generally has a greater effect on perceived value than on satisfaction. It manages to explain $58 \%$ of variance in perceived value indicating that their predictors (i.e. four dimensions of perceived quality) have been well chosen. In this case, the greater weight of perceived value is remarkable, as this finding is the result of a variable that takes into account the management of sporting events. Similar results are provided by (Calabuig et al., 2010a), where it is perceived that management explains 
further spectator satisfaction with the value of an athletic event. However, (Clemes et al., 2011) have found the opposite effect; quality carries greater weight in explaining satisfaction as opposed to perceived value.

This also coincides with Theodorakis et al. (2001) regarding the role of the tangible elements of the event. It is considered as the variable most significant in explaining the perceived value and satisfaction of the spectator. It is also worth noting that the event staff has no influence in predicting both the satisfaction and the perceived value, well as the limited effect of the complementary services as only have minimal effect on satisfaction. Hopefully, in a sporting event in which contact with employees is minimal, its influence is less than, for example, cafeterias, toilets or other concessions.

In short, in terms of the first objective of the research, the data suggest that tangibles, outcome quality and the perceived value of the spectators in a regular sporting event are crucial to explain their overall satisfaction. Furthermore, we observe how the perceived value exerts itself; a strong effect on satisfaction should be borne in mind by the managers of these events if they want to improve the level of satisfaction of the spectators. These results agree in part with Theodorakis et al., (2001), in which the same effect of tangibles on spectator satisfaction is observed. This is also in accordance with Kim et al., (2006) who suggest that quality is a strong predictor of satisfaction.

Regarding the second objective, i.e. the importance of the perceived value and emotions in explaining future intentions and satisfaction of the spectator, it should be noted that the results are interesting and open new avenues of research. Thus, as shown in Figure 2, the perceived value is the variable that has the greatest weight in predicting future intentions of the spectators, and overall satisfaction instead have a much lower weight. This manages to explain $35 \%$ of the variance of future intentions, and although satisfaction also exhibits a significant relationship, the weight is low. Traditionally, satisfaction has been the most influential variable in user intentions; however, based on these results, it should be given more attention, both for the purposes of the professional world and in terms of the academic aspects related to the value perceived by spectators.

Contrary to initial expectations, emotions are not a relevant variable in predicting the satisfaction of the spectator. In this study, only the pleasure dimension has a significant weight. Arousal does not significantly affect spectator satisfaction. These data are consistent only with those of (Calabuig et al., 2015), which found that emotions just moderate the relationship between quality and value but not the others.

Thus, managers of sports events should make efforts to improve the quality of tangibles, complementary services and perceived value of their services to increase the satisfaction of spectators and retain them for the future. Outcome quality also has an important influence both on the perceived value and satisfaction. In short and by way of conclusion, the perceived value becomes a central element in the formation of satisfaction and behavioral intentions of spectators of sports events, and consequently, more should be done to try to dissect the construct of perceived value and to better understand the mechanisms of their formation; ultimately, this will improve the profitability of sports events.

\section{References}

Alexandris, K., Zahariadis, P., Tsorbatzoudis, C., \& Grouios, G. (2004). An empirical investigation of the relationships among service quality, customer satisfaction and psychological commitment in a health club context. European Sport Management Quarterly, 4(1), 36-52. http://doi.org/10.1080/16184740408737466

Anderson J. C, \& Gerbing D. W. (1988). Structural equation modelling in practice: a review and recommended two-step approach. Psychological Bulletin, 103(3), 411-23. http://dx.doi.org/10.1037/0033-2909.103.3.411

Anderson, E. W., Fornell, C., \& Lehmann, D. R. (1994). Customer satisfaction, market share, and profitability: Findings from Sweden. Journal of Marketing, 58(3), 53-66. http://dx.doi.org/10.2307/1252310

Auruskeviciene, V., Pundziene, A., Skudiene, V., Gripsrud, G., Nes, E. B., \& Olsson, U. H. (2010). Change of attitudes and country image after hosting major sport events. Inzinerine Ekonomika-Engineering Economics, 66(1), 53-59.

Baade, R. A., \& Matheson, V. A. (2004). The quest for the cup: Assessing the economic impact of the World Cup. Regional Studies, 38(4), 343-354. http://doi.org/10.1080/03434002000213888

Bagozzi, R. P., Gopinath, M., \& Nyer, P. U. (1999). The role of emotions in marketing. Journal of the Academy of Marketing Science, 27(2), 184-206. http://dx.doi.org/10.1177/0092070399272005

Bagozzi, R. P., \& Yi, Y. (1988). On the evaluation of structural equation models. Journal of the Academy of Marketing Science, 16, 74-94. http://dx.doi.org/10.1007/BF02723327

Baker, D., \& Crompton, J.L. (2000). Quality, satisfaction and behavioral intentions. Annals of Tourism Research, 27(3), 785-804. http://doi.org/10.1016/S0160-7383(99)00108-5

Balciunas, M., Jasinskas, E., \& Koika, E. (2014). Economic contribution of sports event: Analysis of Eurobasket 2011 example. Transformations in Business \& Economics, 13(2), 41-54.

Banyte, J., Tarute, A., \& Taujanskyte, I. (2014). Customer engagement into value creation: Determining factors and relations with loyalty. Inzinerine Ekonomika-Engineering Economics, 25(5), 568-577. http://doi.org/10.5755/j01.ee.25.5.8402

Bentler, P. M., \& Bonett, D. G. (1980). Significance tests and goodness of fit in the analysis of covariance structures. Psychological Bulletin, 88(3), 588. http://dx.doi.org/10.1037/0033-2909.88.3.588 
Bentler, P. M. (1990). Comparative fit indexes in structural models. Psychological Bulletin, 107, $238-46$. http://dx.doi.org/10.1037/0033-2909.107.2.238

Bentler, P. M. (1995). EQS Structural equations program manual. Encino, CA, Multivariate Software, Inc.

Biscaia, R., Correia, A., Rosado, A., Maroco, J., \& Ross, S. (2012). The effects of emotions on football spectators' satisfaction and behavioural intentions. European Sport Management Quarterly, 12(3), $227-242$. http://doi.org/10.1080/16184742.2012.679949

Bodet, G., \& Bernanche-Assollant, I. (2011). Consumer loyalty in sport spectatorship services: The relationship with consumer satisfaction and team identification. Psychology \& Marketing, 28(8), 781-802. http://doi.org/10.1002/mar.20412

Bollen, K. A. (1989). A new incremental fit index for general structural equation models. Sociological Methods \& Research, 17(3), 303-316. http://doi.org/10.1177/0049124189017003004

Browne, M. W., \& Cudeck, R. (1993). Alternative ways of assessing model fit. In: Bollen, K. A. \& Long, J. S. (Eds.) Testing Structural Equation Models, pp.136-162. Beverly Hills, CA: Sage

Byrne, B. (1989). A primer of LISREL: Basic applications and programming for confirmatory factor analytic models. New York: Springer-Verlag. http://dx.doi.org/10.1007/978-1-4613-8885-2

Calabuig, F., Burillo, P., Crespo, J., Mundina, J., \& Gallardo, L. (2010a). Satisfaccion, calidad y valor percibido en espectadores de atletismo [Satisfaction, quality and perceived value in spectators of athletics]. Revista Internacional de Medicina y Ciencias de la Actividad Fisica y el Deporte, 10(40), 577-593.

Calabuig, F., Mundina, J., \& Crespo, J. (2010b). Eventqual: A measure of perceived service quality of sport spectators. Retos, 18, 66-70.

Calabuig, F., Nunez-Pomar, J., Prado-Gasco, V., \& Ano, V. (2014). Effect of price increases on future intentions of sport consumers. Journal of Business Research, 67(5), 729-733. http://doi.org/10.1016/j.jbusres.2013.11.035

Calabuig, F., Prado-Gasco, V., Crespo, J., Nunez-Pomar, J. M., \& Ano, V. (2015). Spectator emotions: Effects on quality, satisfaction, value, and future intentions. Journal of Business Research, 68(7), 1445-1449 http://doi.org/10.1016/j.jbusres.2015.01.031

Carmines, E. G., \& McIver, J. P (1981). Analyzing models with unobserved variables, in G.W. Bohrnstedt, \& E.F. Borgatta (Eds.), Social measurement: Current issues (pp. 65-115). Beverly Hills, CA: Sage.

Chang, H., Wnag, Y., \& Yanga, W. (2009). The impact of e-service quality, customer satisfaction and loyalty on emarketing. Moderating effect of perceived value. Total Quality Management, $20(4), 423-443$. http://dx.doi.org/10.1080/14783360902781923

Chen, Z., \& Dubinsky, A. J. (2003). A conceptual model of perceived customer value in e-commerce: A preliminary investigation. Psychology \& Marketing, 20(4), 323-347. http://dx.doi.org/10.1002/mar.10076

Clemes, M. D., Brush, G. J., \& Collins, M. J. (2011). Analysing the professional sport experience: A hierarchical approach. Sport Management Review, 14(4), 370-388. http://dx.doi.org/10.1016/j.smr.2010.12.004

Crespo, J., Mundina, J., Calabuig, F., \& Aranda, R. (2013). Perceived quality of basketball spectators. A measurement scale validation. Revista de Psicologia del Deporte, 22(1), 195-198.

Cronin, J. J. \& Taylor, S. A. (1992). Measuring service quality: A reexamination and extension. Journal of Marketing, 56(3), 55-68. http://dx.doi.org/10.2307/1252296

Cronin, J. J., Brady, M. K., \& Hult, G. T. (2000). Assessing the effects of quality, value and customer satisfaction on consumer behavioral intentions in service environments. Journal of Retailing, 76(2), 193-218. http://dx.doi.org/10.1016/S0022-4359(00)00028-2

Dodds, W. B., Monroe, K. B., \& Grewal, D. (1991). The effects of price, brand and store information on buyers' product evaluations. Journal of Marketing Research, 28(3), 307-319. http://dx.doi.org/10.2307/3172866

Fornell, C., \& Larcker, D. F. (1981). Evaluating structural equations models with unobservable variables and measurement error. Journal of Marketing Research, 18, 39-50. http://dx.doi.org/10.2307/3151312

Gallarza, M. \& Gil, I. (2006). Value dimensions, perceived value, satisfaction and loyalty: an investigation of university students' travel behavior. Tourism Management, 27(3), 437-452. http://dx.doi.org/10.1016/j.tourman.2004.12.002

Greenwell, T. C., Fink, J. S., \& Pastore, D. L. (2002). Assessing the influence of the physical sports facility on customer satisfaction within the context of service experience. Sport Management Review, 5(2), 129-148. http://dx.doi.org/10.1016/S1441-3523(02)70064-8

Hair, J. F., Black, W. C., Babin, B. J., Anderson, R. E., \& Tatham, R. L. (2006). Multivariate data analysis (6th ed). New York: MacMillion Publishing Company.

Hightower, R., Brady, M. K. \& Baker, T. L. (2002). Investigating the role of the physical environment in hedonic service consumption: an exploratory study of sporting events. Journal of Business Research, 55(9), 697-707. http://dx.doi.org/10.1016/S0148-2963(00)00211-3 
Ferran Calabuig-Moreno, Josep Crespo-Hervas, Juan Nunez-Pomar, Irena Valantine, Inga Staskeviciute-Butiene. Role of...

Hu, L., \& Bentler, P. M. (1999). Cutoff criteria for fit indexes in covariance structure analysis: Conventional criteria versus new alternatives. Structural Equation Modeling: A Multidisciplinary Journal, 6(1), 1-55. http://dx.doi.org/10.1080/10705519909540118

Jin, N., Lee, H., \& Lee, S. (2013). Event quality, perceived value, destination image, and behavioral intention of sports events: The case of the IAAF World Championship, Daegu, 2011. Asia Pacific Journal of Tourism Research, 18(8), 849-864. http://dx.doi.org/10.1080/10941665.2012.711336

Joreskog, K. G., \& Sorbom, D. (2001). LISREL 8.50. Chicago: Scientific Software International.

Kaplan, D. (2000). Structural equation modeling: Foundations and extensions. California, Thousand Oaks: Sage.

Kelley, S. W., \& Turley L. W. (2001). Consumer perceptions of service quality attributes at sporting events. Journal of Business Research, 54(2), 161-166. http://dx.doi.org/10.1016/S0148-2963(99)00084-3

Kim, H., Lavetter, D., \& Lee. J. (2006). The influence of service quality factors on customer satisfaction and repurchase intention in the Korean professional basketball league. International Journal of Applied Sports Sciences, 18(1), 39-58.

Kleinginna Jr, P. R., \& Kleinginna, A. M. (1981). A categorized list of emotion definitions, with suggestions for a consensual definition. Motivation and Emotion, 5(4), 345-379. http://dx.doi.org/10.1007/BF00992553

Kline, R. B. (2005), Principles and practice of structural equation modeling (2nd ed.). New York: The Guilford Press

Ko, Y., Zhang, J., Cattani, K., \& Pastore, D. (2011) Assessment of event quality in major spectator sports. Managing Service Quality, 21(3), 304-322. http://dx.doi.org/10.1108/09604521111127983

Kuenzel, S., \& Yassim, M. (2007). The effect of joy on the behaviour of cricket spectators: The mediating role of satisfaction. Managing Leisure, 12(1), 43-57. http://doi.org/10.1080/13606710601056497

Kwon, H. H., Trail, G. T., \& Anderson, D. (2005). Are points of attachment necessary in predicting cognitive, affective, conative, or behavioral loyalty? A case analysis. Sport Management Review, 8(3), 255-270. http://dx.doi.org/10.1016/S1441-3523(05)70041-3

Lee, J. S., \& Kang, J. H. (2015). Effects of sport event satisfaction on team identification and revisit intent. Sport Marketing Quarterly, 24(4), 225-234.

Lee, J. H., Kim, H. D., Ko, Y. J., \& Sagas, M. (2011). The influence of service quality on satisfaction and intention: A gender segmentation strategy. Sport Management Review, 14(1), 54-63. http://dx.doi.org/10.1016/j.smr.2010.02.002

Lewis, B. R., \& Soureli, M. (2006). The antecedents of consumer loyalty in retail banking. Journal of Consumer Behaviour, 5(1), 15-31. http://dx.doi.org/10.1002/cb.46

McDonald, M. A., Sutton, W. A., \& Milne, G. R. (1995). TEAMQUAL: Measuring service quality in professional team sports. Sport Marketing Quarterly, 4(2), 9-15.

McDougall, G. H., \& Levesque, T. (2000). Customer satisfaction with services: putting perceived value into the equation. Journal of Services Marketing, 14(5), 392-410. http://dx.doi.org/10.1108/08876040010340937

Nunnally, J. C., \& Bernstein, I. H. (1994). Psychometric theory (3rd ed.). New York: McGraw Hill.

Oliver, R.L. (1997). Satisfaction: A behavioral perspective on the consumer. New York: McGraw-Hill.

Parasuraman, A., Zeithaml, V. A., \& Berry, L. L. (1988). SERVQUAL: A multi-item scale for measuring consumer perceptions of service quality. Journal of Retailing, 64(1), 12-40.

Perez-Campos, C., \& Alonso, M. (2013). The importance of service attributes and perceived value in predicting handball spectators' satisfaction. Journal of Sports Economics \& Management, 3(1), 33-46.

Russell, J. A. (1980). A circumplex model of affect. Journal of Personality and Social Psychology, 39(6), 1161-1178. http://dx.doi.org/10.1037/h0077714

Sanchez, R., \& Iniesta, M. A. (2006). Consumer perception of value: Literature review and a new conceptual framework. Journal of Consumer Satisfaction, Dissatisfaction and Complaining Behavior, 19, 40-59.

Shonk, D. J., \& Chelladurai, P. (2008). Service quality, satisfaction, and intent to return in event sport tourism. Journal of Sport Management, 22(5), 587-602.

Sumino, M., \& Harada, M. (2004). Affective experience of J. League fans: the relationship between affective experience, team loyalty and intention to attend. Managing Leisure, 9(4), 181-192. http://dx.doi.org/10.1080/1360671042000273855

Theodorakis, N. \& Alexandris, K. (2008). Can service quality predict spectators' behavioral intentions in professional soccer? Managing Leisure, 13(3), 162-178. http://dx.doi.org/10.1080/13606710802200852

Theodorakis, N. D., Alexandris, K., Tsigilis, N., \& Karvounis, S. (2013). Predicting spectators' behavioural intentions in professional football: The role of satisfaction and service quality. Sport Management Review, 16(1), 85-96. http://dx.doi.org/10.1016/j.smr.2012.05.004

Theodorakis, N., Kambitsis, C., \& Laios, A. (2001). Relationship between measures of service quality and satisfaction of spectators in professional sports. Managing Service Quality, 11(6), 431-438. http://dx.doi.org/10.1108/09604520110410638 
Trail, G. T., Anderson, D. F., \& Fink, J. S. (2005). Consumer satisfaction and identity theory: A model of sport spectator conative loyalty. Sport Marketing Quarterly, 14(2), 98-112.

Tsuji, Y., Bennett, G., \& Zhang, J. (2007). Consumer satisfaction with an action sports event. Sport Marketing Quarterly, 16, 199-208.

Tzetzis, G., Alexandris, K., \& Kapsampeli, S. (2014). Predicting visitors' satisfaction and behavioral intentions from service quality in the context of a small-scale outdoor sport event. International Journal of Event and Festival Management, 5(1), 4-21. http://doi.org/10.1108/IJEFM-04-2013-0006

Wakefield, K. L., \& Blodgett, J. G. (1996). The effect of the servicescape on customers' behavioral intentions in leisure service settings. Journal of Services Marketing, 10(6), 45-61. http://dx.doi.org/10.1108/08876049610148594

Wangenheim, F., \& Bayon, T. (2007). The chain from customer satisfaction via word-of-mouth referrals to new customer acquisition. Academy of Marketing Science Journal, 35(2), 233-249. http://dx.doi.org/10.1007/s11747-007-0037-1

Yang, Z., \& Peterson, R. T. (2004). Customer perceived value, satisfaction, and loyalty: The role of switching costs. Psychology \& Marketing, 21(10), 799-822. http://doi.org/10.1002/mar.20030

Zeithaml, V. A. (1988). Consumer perceptions of price, quality, and value: A means-end model and synthesis of evidence. Journal of Marketing, 52(3), 2-22. http://dx.doi.org/10.2307/1251446

The article has been reviewed.

Received in May 2015; accepted in April, 2016. 